\title{
Recent Recovery of Unpublished Field Notes of Theodore D. McCown's Paleoanthropological Explorations in the Narmada River System, India, 1964-1965
}

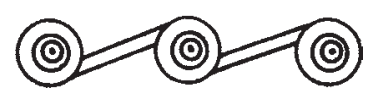

KENNETH A. R. KENNEDY AND ELIZABETH LANGSTROTH

\section{INTRODUCTION}

Since the Discovery in 1982 OF The "Narmada MaN" fossil cranial remains in the middle Narmada (Narbadda) Valley of India (Fig. 1) by the geologist Arun Sonakia, several scholars in the international community of palaeoanthropologists have sought to determine the specimen's antiquity, its stratigraphic context, and the nature of its associated middle Pleistocene stone tools. Removed from the deposit were Acheuliantype hand axes, cleavers, and fossilized bones and teeth of extinct faunal species. Research within the Narmada River system was directed in 1964-1965 by the late Theodore D. McCown (1908-1969) with his team from the University of California at Berkeley. McCown's untimely death and other circumstances precluded the publication of a report of his explorations. However, his handwritten notes (Document 1), letters (Document 3), and a typed list of the locations that he explored with his team (Document 2) have been recovered (Tables 1 and 2). In the present article these materials were copied and minimally edited. They are of historic value and are potentially useful as a guide to a number of sites for investigation by twenty-first-century palaeoanthropologists. These goals can be attained through exploration and excavation of the localities within the Narmada River system, which are discussed and listed here. McCown's interpretation of the prehistoric stone tools and biotic specimens he encountered along the Narmada River and its vicinity is that those artifacts and faunal remains exposed along the present-day flood plain had eroded out of adjacent higher stratigraphic levels of middle Pleistocene age and became re-deposited. His usage of cultural and lithic traditions as Early, Middle, and Late Stone Ages reflects his application to the African system of chronology and diagnostic lithic features current at the time he was writing. Today there is a preference among South Asian prehistorians to identify these lithic-cultural traditions as Early, Middle, and Late Palaeolithic. PostPleistocene (Holocene) stone tool traditions fall within the Late Palaeolithic.

Kenneth A. R. Kennedy is Professor Emeritus at Cornell University, Ithaca, New York. Elizabeth Langstroth is an independent scholar residing in Pacific Grove, California. 


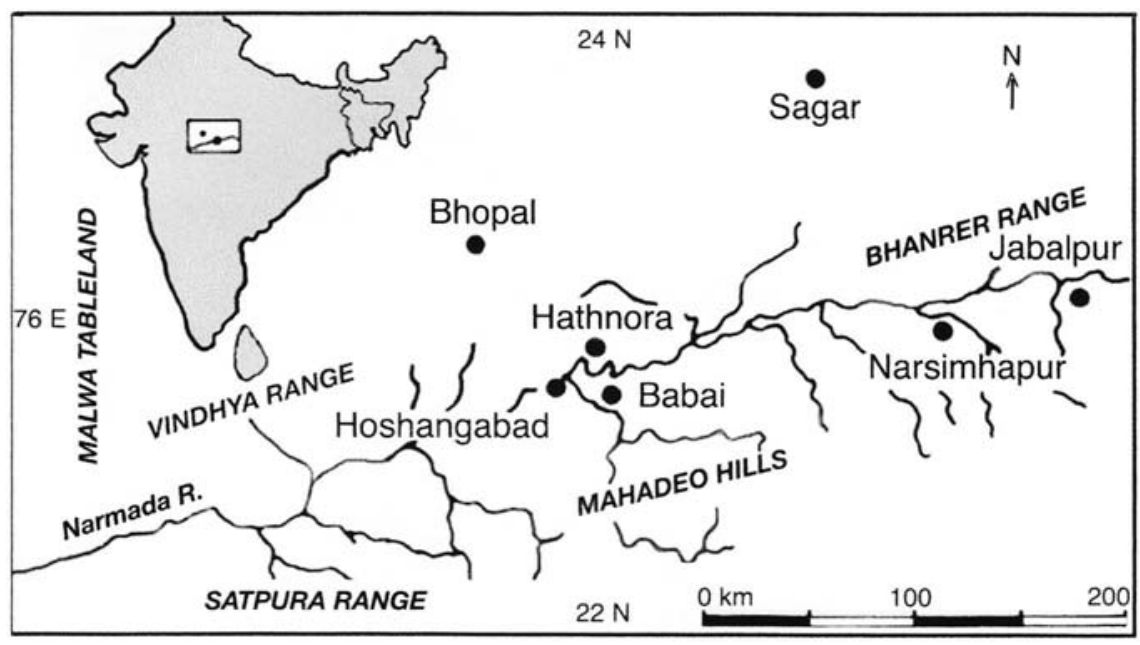

Fig. 1. Focal areas of the 1964-1965 exploration.

Table I. Nineteenth- AND TWENTIETH-CENTURY INVESTigators OF THE GEOlOgy AND PREHISTORY OF THE NARMADA VAlley.

\begin{tabular}{lll}
\hline DATE OF EXPLORATION & \multicolumn{1}{c}{ PUBLISHED RECORD } & \multicolumn{1}{c}{ LOCALITY } \\
\hline 1833 & Spillsbury (1833) & Omar Hadi \\
$1863-1866$ & Blanford (1869) & Lower Narmada Valley \\
$1860-1862$ & Falconer (1868) & Narmada Valley \\
1869 & Vrendenburg (1906) & Narmada Valley \\
ca. early 1830s & Theobald (1860) & Hosangabad to Narsingpur \\
1851 & Medlicott, H. B. (1873) & Bhutra, Vindhyas \\
$1856-1857$ & Medlicott, J. G. (1860) & Narmada Valley \\
1869 & Oldham (1871) & Central Province, Khasi Hills \\
1910 & Pilgrim (1910) & Hosangabad to Narsingpur \\
1922 & Ghosh (1932) & Narmada Valley \\
1935 & De Terra and Patterson (1939) & Adamgarth \\
1957 & Sahni (1956) & Narmada Valley \\
$1958-1959,1959-1960$ & Khatri (1961, 1962, 1963, 1966) & Narmada Valley \\
1962 & Supekar (1968) & Mahadeo Piparia \\
$1964-1965$ & McCown and Shkurkin, in Shkurkin (1976) & Central Narmada Valley \\
1982 & & Harda to Jabalpur \\
\hline
\end{tabular}

\section{DOCUMENT I: HANDWRITTEN FIELD NOTES}

"The proposal I made in connection with the sabbatical leave application for 19641965 was to carry [out] our field research in Central India, primarily in the Narbadda and Tapti Valleys, concentrating on prehistoric archaeological problems of Pleistocene time.

"This area of Central India, especially the middle stretch of the Narmada valley from Harda to Jabalpur, has been regarded for a century as representing the Middle Pleistocene fauna of peninsular India. The presence of ancient man in India has been 
attested by chipped stone tools through discoveries made in the last century and in the Narbudda Valley since the 1930s. Reasonable evidence has been available of tools typologically like Middle Pleistocene tools from Europe and Africa with indications Late Pleistocene and post-Pleistocene forms present also.

"From Jabalpur to the Arabian Sea, the river current turns a little and southwest for a distance of about 150 kilometers. To the south the valley is bounded by the Satpura Range which effectively marks the northern edge of the Deccan Plateau. To the north the Vindhya Range with its continuation westerly of the Malwa Plateau forms a distinct boundary. The valley continues eastward and north of Jabalpur until the water divide is reached which separates the eastward flowing of the Son River. A major river enters the valley south and west of Jabalpur, coming from the southeast, and because of its size is regarded as the upstream continuation of the Narbadda. Physiologically it is a major southern tributary which turns eastward about $300 \mathrm{~km}$ south of Jabalpur and has a source on the mountains that roughly divide this part of Madhya Pradesh from Orissa.

"If the Indus River is excepted, this is India's only flowing river of any length and volume in a major rift valley. A variety of linguistic and cultural thresholds coincide with this region. The mountainous character of the country south and north of the river is ill suited [for] intensive agriculture and thousands of square miles are in reserved forest.

"The survey I made in the spring of 1958 during an earlier sabbatical year convinced me that there were a variety of problems, archaeological and paleontological and geological[, which] repay investigation.

"The interest and helpful association I then received from Prof. H. Sankalia of the Department of Archaeology at the Deccan College and PGRI [Post-Graduate Research Institute], Poona, convinced me that this location would make an excellent base of operations. Further the size of the area and the spatial separation of reported Pleistocene prehistoric localities made it clear that a maximum amount of time for field work would be desirable. The monsoonal climate makes travel with motor vehicles, away from main roads, reasonably possible from late September to early June, but from mid-April until mid-June day and night temperatures generally stay above 90 degrees F. and mid-day temperatures of 110 degrees F or higher make field work difficult.

"The 1958 reconnaissance produced a number of ideas:

(1) Indian and non-Indian pre-historians were using a model to infer climatic change from pedology derived from Europe, and the model has been shown to apply imperfectly in the area of origin. I doubted whether it applied any more accurately in India.

(2) The survey efforts of the Indian pre-historians concentrated on the materials from the silts and gravels exposed in banks of the present main channel of the river. These banks vary from 100 feet [to] c. 50-60 feet above low water level, the latter values being the most common ones.

(3) Much of the claimed artifact material was heavily rolled and battered. My experience with European and Near Eastern Paleolithic induced some skepticism as to the human workmanship of some but not all of these 'tools.'

(4) The fossil found materials, represented by some hundreds of fragments both in Europe (BMNH, London) [British Museum of Natural History] and in India, 
had been mainly accumulated piece by piece over a period of a century and a half; little of it had any precise provenance, and no 'bone pits' had ever been reported.

(5) Since the middle and lower course of the main river is clearly dependent on the tributaries for the erosion and transporting power, it seemed reasonable to examine some of these when they issue from the mountains. This 'hilly flanks' idea I determined to pursue on returning to India. Little or undisturbed living sites would form most desirable discoveries.

"I left Berkeley on August 27, 1964, with my family by ship for Japan and continue by the same means to Bombay, [discussion of travel arrangements]. We arrived in Poona on 5 October. A week later Mr. George Shkurkin joined me. Mr. Shkurkin had come by my invitation, a candidate for the Ph.D. in Anthropology in this department [Department of Anthropology, University of California at Berkeley] and with a background as a major in palaeontology on this campus and subsequent post-graduate work in prehistoric archaeology at the University of Heidelberg.

"With the help of Prof. Sankalia, Deccan College, I engaged Mr. S. Superkar as an archaeological assistant. Mr. Superkar is a candidate for the Ph.D. in prehistoric archaeology at the Deccan College, and had surveyed and excavated in the Narmada Valley. With the arrival of our heavy baggage containing essential field equipment at the end of the first week in November, it was possible to leave Poona after the middle of the month and procede [sic] to the Narmada Valley.

"Our first day's journey took us across the eastern part of the Deccan plateau to Mulanager. The plateau is basalt with eroded flat-topped mesas, very like Nevada and eastern Oregon. Mulangar is the site of an irrigation dam to impound the waters of the great Godavari River. Colleagues at Deccan College had suggested that the milelong cut exposing a hundred feet of alluvium was worth a visit and as it proved to be. In the few hours of the afternoon which we could devote to examining this situation, several things became obvious. The present bed of the river is at least 60 [feet] higher than its most ancient bed. The overall history of the river, in this part of its course, is an overall balance of aggradation, with no clear evidence of more than minor episodes of erosion leading to the fashioning of new channels. No artifacts were discovered but the dam engineers did recover both fragile remains or buried palm trunks and a small quantity of mammal fossils from the lower 50 feet of the alluvial fill.

"On November 28 we examined a deep excavation at Yeldari Dam, at the Purna River. Here was a channel eroded in the basalt [at] least 60 feet below the present bed of the river, and filled with alluviam from which had been recovered fragments of Elephas and Bos, plus other undetermined specimens. Here again the evidence suggested that the tributary of the Godvari had been shifting laterally and aggrading more than down cutting with no visible evidence that this latter process had been arrested for any period of time.

"December 1 and 2 we spent in Nagpur to secure the vehicles, do some banking and visit the headquarters or the Prehistoric Section of the Archaeological Survey of India and renew acquaintance with Drs. Joshi and Bannerjee.

"By December 5 we had reached the Narmada river at the town of Mandia. Some Middle Stone Age material, much rolled, was encountered on the river banks, but most interesting was the basalt formation that dams the overflow [of the] town and creates a falls of about 15 feet. The following day we went by vehicle upstream to the 
village of Ramnagar, and where there is another dike of basalt forming a -------[?], and we took a boat to proceed at a leisurely pace downstream to Mandia. Impressive cliffs and silt, generally 60 feet in height, form the banks of the river for over 15 miles with little undulation of cross bedding and no gravel lenses. The artifacts were discovered at our landfalls with one exception. The river flows at a speed of 1 to 2 miles per hour and the enormous accumulations of silt can usually be accounted for by the basalt 'dam' below Mandia.

"Between Mandia and Jabulpur we stopped at the village and 'tribal' school at Kalpi. Here we encountered patinated but unrolled MSA flakes and cores, and near the Rest House, a small scatter of microliths. Karpi is one mile away from and much higher than the Narbadda and this was my first direct observation that palaeoliths occur elsewhere than in the river alluvium.

"Three days were spent at Jabulpur. The first was devoted to an examination of the Marble Rocks area, west of Jabulpur, Our Indian colleagues had spoken repeatedly of the importance of this deposits in the right bank below the Marble Rocks. As much as 60 feet of alluvial deposits rise above the water level of the river. There is an irregular degree of concentration lenses; levels of sand and gravel occur at varying amounts and at varying elevations. Some appear to be the sources of both rolled and fairly fresh MSA flakes. Vertical sections only 10 feet apart show completely different strata successions. At 20 carefully controlled clean sections would be required and their correlation would be very difficult. The alluvium is complicated and may reflect varying degrees of river control by the upstream barrier of the Marble Rocks.

"The two following days were spent in reconnaissance for about 40 miles along the road to Mandle and in the nearer environs of Jabalpur. On the road to Niwas a location was found in which a thin but extensive scatter of unrolled MSA material was recovered from reddish soil, all of this a thin layer of basalt.

"Two days were used to move from Japalpur to Narsingpur, with an overnight halt at Mingwani and frequent stops for exploration of likely localities. We reached Narsingpur on Monday of the 12th of December and spent the afternoon in the Divakachar-Umania area. This is one of the localities known from the occurrence of fossil mammals. The general situation is one in which this material is being eroded mainly from clay and salt beds and salt beds appear sporadically after the monsoon floods, and contains pieces that suggest prior fossilization and redeposition. Lithic material of any value was scant. No sizable pockets or beds of fossil material appear to exist and systematic collecting so long after the monsoon seemed unpromising.

"On Sunday the 13th we crossed the Narmada on the new bridge above Barman Ghat and went north along the highway of Saugar. Turning east and along the alluvial plain, we proceeded to Kumharana village and about 1-1/2 miles east of the village the country road crossed as wide, meandering valley. In the bed were numerous gravel and cobble bars and searching these we found a considerable amount of ESA [Early Stone Age] material, some of it fresh appearing, some rolled, but with several good cleavers and handaxes. We examined the nullah for several hundred yards both up and downstream. A reasonably continuous gravel bed was exposed in the banks, overlain in places by 20-30 feet of light brown silt. Below the gravel was what we took to be a yellow to gray laminated clay, steeply dipping and with the gravel lying uncomfortably in it. The gravel was the source of the artifacts. This was obviously an area worthy of intensive examination." 


\section{DOCUMENT 2: TYPED FIELD NOTES}

A typed record was provided by Mr. Shkurkin, then a graduate student in Anthropology at the University of California at Berkeley, who accompanied Prof. McCown during the 1964-1965 period of exploration of the Narmada Valley system. His listing of localities visited by him and other members of McCown's exploration team includes data from Document 1 as well as information aobut other areas in which prehistoric artifacts were encountered. The present author summarizes those parts of Mr. Shkurkin's typewritten notes that are organized according to the succession of dates of their investigation, and the types and chronological contexts of the lithic materials (Table 2).

THANVAR RIVER: MSA (Middle Stone Age) tools were found within coarse gravel patches on sand deposits on the right bank of the river near Nianpur Rest House. Blades, cores, and pottery were present 6 to 10 inches below the gorund surface.

MANDLA: On the right bank of the Thanvar River MSA flakes were found in situ. At the Forest Rest House unrolled flakes and cores were observed.

MARBLE ROCKS: MSA tools appeared in a Late Pleistocene deposit.

NAGA BABU: MSA tools were encountered in ploughed fields. Tools exhibit rolling.

Table 2. Major localities with prehistoric stone tools in the Narmada System AND ITS VICINITY VISITED IN I964-I965.

\begin{tabular}{lll}
\hline SITE NAME & \multicolumn{1}{c}{ Relative DATE } & STONE TOOL TRADITION* \\
\hline Adamgarh & Late Pleistocene and Post-Pleistocene & MSA and LSA \\
Balain Nulla & Late Pleistocene & MSA \\
Barman Ghat & Middle Pleistocene and Post-Pleistocene & ESA and LSA \\
Bijadandi & Late Pleistocene & MSA \\
Bijawar & Middle Pleistocene and Late Pleistocene & MSA and LSA \\
Delikhari & Late Pleistocene & MSA \\
Dindori & Late Pleistocene & MSA \\
Haslpur & Middle Pleistocene & ESA \\
Kalpi & Late Pleistocene & MSA \\
Karhan & Middle Pleistocene & ESA \\
Kumhorora & Middle Pleistocene and Post-Pleistocene & ESA and LSA \\
Mahda Piparia & Middle Pleistocene & ESA \\
Mandla & Late Pleistocene & MSA \\
Marble Rock & Late Pleistocene & MSA \\
Mahde Pipario & Middle Pleistocene & ESA \\
Nagar Babu & Late Pleistocene & MSA \\
Nainpur & Post-Pleistocene & LSA \\
Narsingpur & Middle Pleistocene & MSA (Narsingpur) \\
Pahadi Kheda & Late Pleistocene & MSA \\
Peeda Naillah & Middle Pleistocene & ESA and MSA \\
Sher Bridge & Late Pleistocene & MSA \\
Singhanma & Post-Pleistocene & LSA \\
Spillway & Post-Pleistocene & LSA \\
Tawa Confluence & Post-Pleistocene & LSA \\
Travana River & Middle Pleistocene and Late Pleistocene & ESA and MSA \\
\hline & &
\end{tabular}

* Generally accepted dates for these Stone Age categories are 7.0-5.0 million years for the Pliocene; 4.0-0.10 years for the Pleistocene; 10,000 years to the Holocene (Recent). 
PAHADHI KHEDA: Fresh MSA tools found in village fields weathering out of a red soil.

SHER RIVER CROSSING: Several sites in this area showed unrolled but patinated flakes and cores in an uncertain geological context.

PEERA NULLA: EST, both fresh and rolled, in patches found in a nullah within the walls of which were cleavers, flakes, a single handaxe, and pebble choppers. ESA and MSA tools were present at the further end of the nullnah.

DELAKHARI: Probable NSA tools found in the area of this village.

SPILLWAY: LSA core tools were embedded in a gravel conglomerate within a trench.

HASILPUR: Flakes and cores of ESA types were seen within the conglomerate of the river bed.

KUMHRORA: Handaxes and cleavers were found deposited inVindhya sandstone in this area, and quartzite was one of the raw materials used. One handaxe was made of limestone, and other tools of chert and limestone of ESA were found on a hill at a river crossing of boulder gravel. These were encountered at the area of the GarhaSomnapur road crossing. MSA tools found in the immediate vicinity.

NARSINGPUR: Sandstone and quartzite predominate in this area which contains ESA tools and absence of MSA industry just east of the Bijawar Hills.

DELIKHERI: Some MSA material was eroded out of a boulder bed capped with a brown silt, but ESA tools not present.

S1NGANAMA: A "few chips" were observed in the left bank of a nullnah and could be of LSA manufacture.

DINORI: MSA industry found at four locations on the Jabalapur-Narsingpur road. Flakes and cores were made with the Levallois technique of LSA were collected in a nullnah. Also fluted cores, flakes and blades of chalcedony.

Not included in Shkurkin's list is the site of Mahadeo Piparia excavated by Supekar in the 1960s and visited by McCown and Shkurkin (Fig. 2).

\section{DOCUMENT 3: LETTERS TO ELIZABETH MCCOWN}

McCown wrote seven letters to his wife (Elizabeth McCown; now Elizabeth Langstroth) and three young daughters (Faith, Anne, and Jean McCown) between January 2 and February 1, 1965. Copies of these communications came into the possession of the present writer, who recognized that they might supplement the written and typed documents materials noted above. They were written when McCown and Shkurkin were surveying the regions of the Mula dam with its associated alluvial deposits and localities of Ahmednagar, Aursugabad, and Jaina. Late Stone Age artifacts were encountered at the upper beds along with fossilized mammalian remains, with all of the collections forwarded to Deccan College.

According to the letters, explorations extended to the localities of Chikhli and Klalingaon, then on to the Tawa dam and Marshi. The cuts into the deposits adjacent to the dam were investigated, as well as the region of the confluence of the Denwa and Tawa rivers. Although human remains and artifacts were not recovered here, the locality is of interest because it provided the raw material for lithic remains in its environs. Some LSA cores and flakes and elephant molar teeth were observed at this locale. This day ended with the mapping of rock shelters along the banks of the Narmada River. 


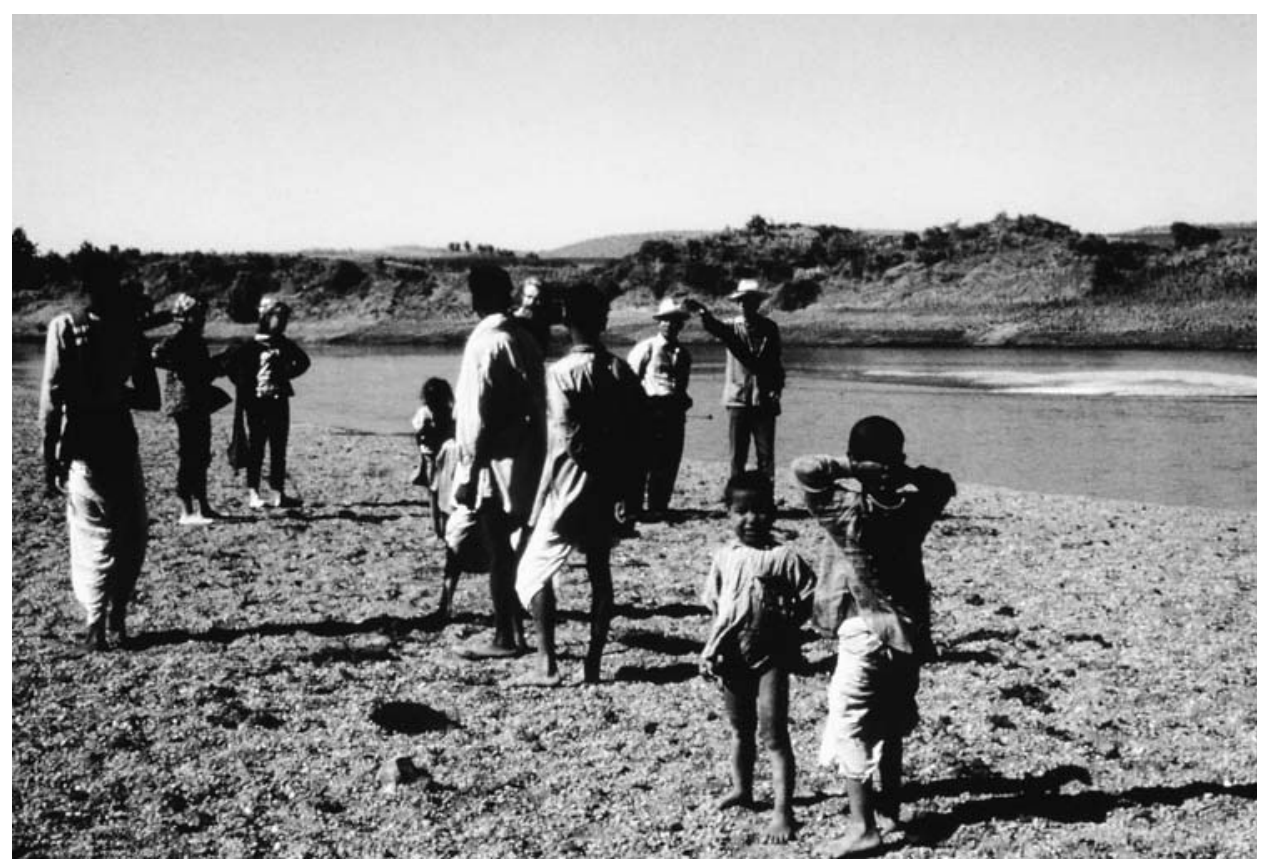

Fig. 2. Narmada Valley alluvial plain near the site of Mahadeo Piparia, 1965.

Other subjects of these letters include details of Rest Houses facilities, equipment, landrover repairs, weather, and areas covered until February 1 when McCown was united with his family at Narsingpur. The places visited during this period of time provide confirmation of the itinerary prepared by Shkurkin.

\section{DISCUSSION}

During the periods of McCown's explorations of the Narmada river system in 1957 and 1964-1965, palaeoanthropologists relied primarily on relative dating methods with respect to geological terrace sequences, regional stratigraphic sequences, biochronology of extinct index fauna, lithic typology, and various palaeoenvironmental signatures (Chauhan 2009). Prior to employment of today's broad spectrum of chronometric (absolute) dating methods, McCown and his colleagues recognized that Adieulean-type stone tools were deposited in the Boulder Conglomerate overlying the Deccan traps. The Acheulean tradition has been dated to the middle Pleistocene in Europe, Africa, and the Levant, thus it is concluded that the recovery of handayes, cleavers, and flake tools in South Asia falls within this geological epoch.

The Narmada River extends $1200 \mathrm{~km}$ from Arnarkantak westward to the Gulf of Cambay, a part of the rift that transverses the entire subcontinent (Shkurkin 1976). The central Narmada valley is one section of the dispersion of the Boulder Conglomerate falling within the Sarajkund Formation as a relict terrace containing Acheulean stone tools. In 1957, McCown collected over 200 lithic specimens from the middle Narmada riverbed. These were examined at Deccan College, Pune, and at 
the University of California at Berkeley (Jayaswal 1978; Semans 1980, 1981) where they served as relative dating indicators for the middle Pleistocene and later geological deposits in the areas of exploration.

Had a report of McCown's 1964-1965 research in the central Narmada valley been published, it would have prompted Indian and foreign palaeoanthropologists to initiate further studies of the region based upon the localities he had explored. Of course other scholars did carry on investigations (Joshi 1978; Khatri 1966; Supekar 1968, 1985), but a significant stimulus followed the discovery in 1984 of the "Narmada Man" fossil calvarium by Sonakia (1984) in the Narmada valley alluvium near Hathnora. Questions about the specimen's morphological and mensural characteristics, antiquity, archaeological and biotic context, and taxonomic status are the focus of a number of scientific efforts that mark present-day foci of investigation of the Narmada data as well as the scope of hominin evolution in South Asia.

It is not the intent of this study to review the major developments in South Asian palaeoanthropology since the time of McCown's explorations over half a century ago. Progress is evident from published sources concerning the application of a diversity of chronometric dating methods (Agrawal 1988; Khatri 1961, 1962, 1963, 1966); taxonomy of South Asian prehistoric human skeletal remains, including the Hathnora "Narmada Man" (Athreva 2007; Cameron et al. 2004; De Lumley and Sonakia 1985; Kennedy 2007; Kennedy et al. 1991); geology (Badam 1989; Sahni 1956); archaeology (Chauhan 2009; Dennell 2007; Patel 2010; Patniak et al. 2009; Rendell and Dennell 1985); and palaeoanthropology (Kennedy 1999, 2000; Kennedy and Jahorski 1997). A brief summary of these sources discloses that hominins have been in South Asia since the late Pliocene, perhaps as early as 2.2 mya; the Acheulean lithic tradition succeeded a chopper/pebble tool tradition c. 700,000 years ago; anatomically archaic Homo sapiens (H. heidelbergensis) first appeared around this time; anatomically modem Homo sapiens were present c. 75,000 to 50,000 years ago; Late Stone Age or Mesolithic microlithic tool traditions were established in Sri Lanka by 38,000 years ago (Kennedy 1999).

McCown's observation in 1965, as recorded above, was that "The survey I made in the spring of 1958 during an earlier sabbatical year convinced me that there were a variety of problems, archaeological and palaeontological and geological[, which] repay investigation." Here is a mantra for present-day and future palaeoanthropologists of South Asian prehistory whose privilege and honor it will be to bring the Indian subcontinent into the broad arena of world prehistory.

\section{ACKNOWLEDGMENTS}

The compilers of these historic documents are indebted to Dr. Alan J. Almquist of the California State University at Hayward who provided us with the late Dr. Theodore D. McCown's handwritten report of his 1964-1965 explorations of the central Narmada valley; to Mr. George V. Shkurkin, presently living in Berkeley, California, for the copy of his notes of the localities visited and lithic materials encountered during 1964-1965; to Mrs. Paula DiSanto Bensadoun of Ithaca, New York, for her rendering of the map (Fig. 1); to Miss Laura Linke, Research Librarian in the Kroch Library, Cornell University, for her help with the entries in Table 1; and to Mrs. Janeen Ott of the Department of Ecology and Evolutionary Biology, Cornell University, for her clerical assistance. 


\section{REFERENCES CITED}

Agrawal, D. P.

1988 Chronology and significance of the Narmada formation. Proceedings of the Indian National Science Academy Part A: 418-424.

Athreva, S.

2007 Was Homo heidelbergensis in South Asia? A test using the Narmada fossil from central India, in The Evolution and History of Human Populations in South Asia: 137-170, ed. M. D. Petraglia and B. Aftchin. Dordrecht: Springer.

BADAM, G. L.

1989 Observations on the fossil hominid site at Hathnora, Madhya Pradesh, in Perspectives in Human Evolution: 153-172. ed. A Sahni and R. Guar. Delhi: Renaissance Publishing House.

BLANFORD, W. T.

1869 On the geology of the Taptee and lower Nerbudda valley and some adjoining districts. Memoirs of the Geological Survey of India 6(3): 163-282.

Cameron, D. R., R. Patniak, and S. Sahni

2004 The phylogenetic significance of the Middle Pleistocene Narmada hominin crania from central India. International Journal of Osteoarchaeology 14(6) : 419-447.

Chauhan, P. R.

2009 The Lower Palaeolithic of the Indian subcontinent. Evolutionary Anthropology 18:62-78.

De Lumley, H., and A. Sonakia

1985 Premiere decouverte d'un Homo erectus dans le moyennevalee de la Narmada. L'Anthropologie 89:13-61.

DenNell, R. W.

2007 Research-rich, stone poor: Early hominin land use in large river systems in northern India and Pakistan, in The Evolution and History of Human Populations in South Asia: Interdisciplinary Studies in Archaeology, Biological Anthropology, Linguistics and Genetics: 41-68, ed. M. D. Petraglia and B. Allchin. Dordrecht: Springer.

De Terra, H., and Teilhard de Chardin

1936 Observations on the upper Siwalik Formation and later Pleistocene deposits in India. Proceedings of the American Philosophical Society 76:791-882.

De Terra, H., and T. T. Paterson

1939 Studies on the Ice Age in India and associated human cultures. Carnegie Institute of Washington Publication 393.

FALCONER, H.

1868 Descriptive catalogue of the fossil remains from the Siwalik Hills, the Narmada, Perim Island, etc. Palaeontological Memoirs and Notes, Charles Murchinson, ed. Fauna Antigua Sivalensis 1.

GHosh, M.

1932 Rock paintings and other antiquities of prehistoric and later times. Memoirs of the Archaeological Survey of India 24.

JAYASWAL, V.

1978 The Palaeohistory of India: A Study of the Prepared Core Technique. New Delhi: Agam Kala Prakashan.

Joshi, R. V.

1978 Stone Age Cultures of Central India: Report of the Excavations of Rockshelters at Adamgarh, Madyha Pradesh. Poona: Deccan College.

KENNEDy, K.A.R.

1999 Palaeoanthropology of South Asia. Evolutionary Anthropology 8(5) :157-194.

2000 God-Apes and Fossil Men: Palaeoanthropology of South Asia. Ann Arbor: University of Michigan Press.

2007 The Narmada fossil hominid, in Human Origins, Genome and People of India: Palaeontological and Archaeological Evidence: 188-192, ed. A. R. Sankyan and V. R. Rao.

Kennedy, K.A.R., A. Sonakia, J. Chiment, and K. K. Verma

1991 Is the Narmada hominid a Homo erectus? American Journal of Physical Anthropology 86(4) : 475496. 
KeNNEDy, K.A.R., AND J. JaHORSKy

1997 Trends in prehistoric technology and biological adaptations: New evidence from Pleistocene deposits at Fa Hien Cave, Sri Lanka, in South Asian Archaeology 1995 :839-853, ed. R. Allchin and B. Allchin. Cambridge: The Ancient India and Iran Trust.

Khatri, A. P.

1961 Stone Age and Pleistocene chronology of the Narmada valley. Anthropos 56:519-530.

1962 A century of prehistoric research in India. Asian Perspectives 6(1-2): 169-185.

1963 Recent explorations for the remains of early man in India. Asian Perspectives 7 (1-2):160192.

1966 The Pleistocene mammalian fossils of the Narmada river valley and their horizons. Asian Perspectives 9:113-133.

Medicott, H. B.

1873 Notes on a cult found by Mr. Hacket (Pliocene of Falconer). Records of the Geological Survey of India 2(5) : 49-57.

Medicoti, J. G.

1860 On the glacial structure of the central portion of the Nerbudda District. Memoirs of the Geological Survey of India 6(1):9-17.

Oldham, T.

1871 Sketch of the geology of the Central Province. Records of the Geological Survey of India 4(3):6982.

PATEl, S. S.

2010 Stone Age India. Archaeology 63(1):28-34.

Patniak, R., P. R. Chauhan, M. R. Rao, B.A.B. Blackwell, A. R. Skinner, A. Sahni, M. S. Chauhan, and H. S. Khan

2009 New geochronological, paleoclimatological, and archaeological data from the Narmada Valley hominin locality, central India. Journal of Human Evolution 56:114-133.

Pilgrim, G. E.

1910 Notices of new mammalian genera and species of the Tertiary of India. Records of the Geological Survey of India $40: 53-71$.

Rendell, H., and R. W. Dennell

1985 Dated Lower Palaeolithic artifacts from northern Pakistan. Current Anthropology 26:293.

SAHNI, M. R.

1956 A century of palaeoanthropology and prehistory in India and adjacent countries. Journal of the Palaeoanthropological Society of India. 1(1):7-51.

Semans, C. A.

1980 Analysis of an Acheulean Collection from Peera Nullah, Narmada Valley, India. Ph.D. diss. University of California, Berkeley.

1981 Analysis of an Acheulean collection from Peera Nulah, Narmada Valley, India. Man and Environment $5: 13-31$.

Shkurkin, G. V.

1976 An attempt to analyze the so-called Middle Pleistocene deposits of the Narmada with respect to climatic conditions during their deposition, in Ecological Backgrounds of South Asian Prehistory, ed. K.A.R. Kennedy and G. L. Possehl. Ithaca, NY: Occasional Papers of Cornell University South Asia Program 7.

SONAKIA, A.

1984 A skull-cap of early man and associated mammalian fauna from Narmada Valley alluvium, Hosangabad area, Madhya Pradesh (India). Records of the Geological Survey of India 113:159172.

Spillsbury, G. G.

1833 Account of the fossil bones discovered in the bed of Omar Nadi near Narsinhpur or Gawar in the valley of the Nerbudda. Journal of the Asiatic Society of Bengal 2:388-395.

SupeKar, S. G.

1968 Pleistocene Stratigraphy and Prehistoric Archaeology of the Central Narmada Basin, 2 vols. Ph.D. diss. Deccan College, Poona.

1985 Some observations of the Quaternary stratigraphy of the central Narmada basin, in Recent Advances in Indo-Pacific Prehistory: 19-27, ed. V. N. Misra and P. Bellwood. New Delhi: Oxford $\mathrm{IBH}$. 
Theobald, W.

1860 On the Tertiary and alluvial deposits of the central portion of the Narbudda valley. Memoirs of the Geological Society of India 14(1): 66-125.

VRENDENBURG, E.

1906 Pleistocene movements as indicated by irregularities of the Narmada and other rivers in the Indian peninsula. Records of the Geological Survey of India 33:33-45.

\section{ABSTRACT}

The 1982 discovery of the "Narmada Man" middle Pleistocene fossil cranial remains by geologist Arun Sonakia in the Narmada valley of India raised a number of questions about the crania's antiquity, stratigraphic context, and nature of associated lithic cultural materials. Although archaeological research had been carried out in 1964-1965 in the region by a research team led by Theodore McCown from the University of California at Berkley, Dr. McCown's untimely death left the results of the his team's investigations unpublished and difficult to access by other scholars. Recently recovered field notes from this archaeological project, reporting on the locations of investigated sites, some specifics of the tools recovered and their probable cultural chronologies, and other observations significant to understanding the Palaeolithic prehistory of the Narmada valley, are presented by the authors along with commentary about significance of these field notes for future research in the region. KEYwORDs: palaeoanthropology, India, Narmada valley, palaeolithic, Acheulean. 